Jurnal Indonesia Sosial Teknologi: p-ISSN: 2723 - 6609

e-ISSN : 2745-5254

Vol. 2, No. 3 Maret 2021

\title{
ANALISIS SERAPAN ANGGARAN PADA INSTANSI BADAN LAYANAN UMUM
}

\section{Yulnaezar Pramudya}

Universitas Jenderal Soedirman, Purwokerto

Email: yulnaezarpramudya@gmail.com

\section{Abstract}

Aims of this study are to determine factors that influence budget consumption in government agencies especially of Public Service Board. This study uses a quantitative method with a questionnaire approach that is filled in by individuals who have experience in financial management and disbursement of funds. This study examines three factors that influence the level of budget absorption at BLU and BLUD. These factors include changes in budgets, quality of human resources, and external pressures. After being identified using data analysis techniques, the results from 63 respondents were only partially quality human resources quality that had an effect on budget absorption. Meanwhile, simultaneously, the three of them have an effect on budget absorption.

Keyword: budget consumption; budget changes; quality of human resources; external pressures; public service board

\begin{abstract}
Abstrak
Tujuan penelitian ini adalah untuk mengetahui faktor-faktor yang mempengaruhi serapan anggaran pada instansi pemerintah khususnya Badan Layanan Umum. Penelitian ini menggunakan metode kuantitatif dengan pendekatan kuesioner yang diisi oleh individu yang memiliki pengalaman dalam pengelolaan keuangan dan pencairan anggaran. Penelitian ini mengkaji tiga faktor yang mempengaruhi tingkat penyerapan anggaran di instansi BLU dan BLUD. Faktor-faktor tersebut antara lain perubahan anggaran, kualitas sumber daya manusia, dan tekanan eksternal. Setelah diidentifikasi menggunakan teknik analisis data, dari 63 responden didapatkan hasil bahwa secara parsial hanya kualitas SDM yang berpengaruh terhadap penyerapan anggaran. Sedangkan secara simultan ketiganya berpengaruh terhadap penyerapan anggaran.
\end{abstract}

Kata kunci: serapan anggaran; perubahan anggaran; kualitas sumber daya manusia; tekanan eksternal; badan layanan umum

\section{Pendahuluan}

Anggaran adalah rencana capaian yang dirumuskan dengan sistematis yang mencakup semua kegiatan organisasi, yang disajikan dalam unit keuangan (currency units) dan efektif untuk masa depan (Putri, 2015). Menurut (Yulianti, 2019) memberikan pendapat bahwa anggaran yang tidak berdasar pada kinerja dapat 
mengacaukan tujuan organisasi sehingga tahap perencanaan anggaran menjadi sangat penting. Anggaran adalah rencana tindakan yang dirancang untuk mendorong pencapaian tujuan organisasi. Dalam sebuah organisasi, anggaran mencakup gambaran mengenai situasi keuangan, termasuk pendapatan, pengeluaran, dan kegiatan yang direncanakan. Agar anggaran dapat berfungsi dengan baik maka rencana anggaran harus meliputi semua kegiatan organisasi.

Rencana Bisnis Anggaran (RBA) pada instansi pemerintah berbentuk Badan Layanan Umum (BLU) dapat dikategorikan sebagai bentuk penganggaran dengan basis kinerja karena mengacu pada Peraturan Pemerintah Nomor 23 Tahun 2005 yang mengatur akan tata kelola keuangan BLU. RBA adalah suatu bentuk dokumen perencanaan usaha serta anggaran didalamnya memuat rencana, jenis kegiatan, dan output kinerja dari perencanaan tersebut. Dasar penyusunan anggaran berasal dari perkiraan pendapatan yang diharapkan diterima dari masyarakat. RBA yang telah terbentuk harapannya dapat meningkatkan akuntabilitas, fleksibilitas, efisiensi, dan transparansi unit dalam pelaksanaan tugas dalam mengelola anggaran.

Salah satu cara kebijakan fiskal pemerintah untuk mendorong pembangunan ekonomi adalah melalui konsumsi pemerintah (belanja / pengeluaran pemerintah). Pada dasarnya belanja pemerintah ini ditujukan untuk mengakomodir barang dan jasa serta pemenuhan kebutuhan dasar masyarakat untuk perputaran ekonomi yang tidak dapat disediakan oleh swasta. Konsumsi pemerintah semacam ini disebut penyerapan anggaran. Biasanya penyerapan anggaran dilakukan dengan membandingkan realisasi anggaran dengan anggarannya. Melalui tingkat penyerapan anggaran kita dapat melihat kinerja dan kapasitas instansi pemerintah dalam melaksanakan dan mempertanggungjawabkan atas segala kegiatan yang direncanakan (Mardiasmo \& MBA, 2009). Semakin optimal diserapnya anggaran untuk realisasi berbagai kegiatan maka semakin baik fasilitas dan layanan umum yang dapat dinikmati masyarakat.

Telah banyak penelitian tentang penyerapan anggaran. Variabel yang digunakan seperti perencanaan, perubahan anggaran, pemahaman karyawan, pelatihan, pengaruh eksternal, dan komitmen organisasi. Namun hasilnya banyak berbeda antar peneliti. Penelitian (Lestari et al., 2014), menyimpulkan bahwa perubahan anggaran berdampak positif terhadap penyerapan anggaran pemerintah daerah. (Yulianti, 2019) mengemukakan bahwa perubahan anggaran berdampak negatif terhadap penyerapan anggaran instansi pemerintah pusat (Santoso, 2017). Bertentangan dengan pandangan (Rifai \& Inapty, 2016) yang menemukan bahwa sumber daya manusia, regulasi, dan perencanaan tidak akan mempengaruhi terlambatnya penyerapan anggaran.

Menurut (Andriati, 2019) berpendapat bahwa keterlambatan turunnya dana merupakan alasan untuk tidak melaksanakan atau menunda proyek yang sedang berjalan dan kegiatan yang telah direncanakan. Proyek dan kegiatan yang direncanakan tersebut terutama membutuhkan arus kas, oleh karena itu tanggung jawab pengelolaan keuangan merupakan hal yang penting dan berdampak besar terhadap penyerapan anggaran (Dewi \& Purbawangsa, 2018). Menyimpulkan bahwa pengetahuan keuangan dapat membantu individu terhindar dari masalah keuangan, terutama masalah yang disebabkan oleh 
pengelolaan keuangan yang buruk. Pengetahuan keuangan pribadi tidak hanya sekedar ilmu atau teori, tetapi diharapkan dapat menjadikan individu lebih baik dan bijak dalam mengelola aset sehingga dapat memberikan umpan balik yang berguna untuk mendukung pengelolaan keuangan dalam jangka pendek dan jangka panjang.

Perbedaan hasil kajian sebelumnya antara instansi pusat dan daerah menjadi fokus utama kajian ini. Tujuan dari penelitian ini adalah untuk menguji faktor-faktor yang dapat mempengaruhi tingkat penyerapan anggaran. Faktor-faktor tersebut akan diujikan pada instansi pemerintah dalam bentuk badan layanan publik (berupa BLU pusat dan BLU daerah sebagai badan pengelola anggaran). Instansi BLU dinilai memiliki fleksibilitas finansial yang luas karena bisa langsung menyesuaikan pendapatan untuk biaya operasional.

Menurut peraturan tentang keuangan negara yang diatur pada UU Nomor 17 Tahun 2003, anggaran merupakan alat pertanggungjawaban, pengelolaan, dan kebijakan ekonomi (Halim \& Kusufi, 2007). Mengemukakan bahwa anggaran publik adalah dokumen yang menyajikan status keuangan suatu organisasi berupa informasi tentang pendapatan, pengeluaran, dan kegiatan.

Organisasi sektor publik pada dasarnya dibentuk atas agency theory. Pertanggungjawaban dalam organisasi sektor publik memiliki arti bahwa dalam tata kelola pemerintah daerah terdapat hubungan keagenan antara masyarakat sebagai principal dan pemerintah sebagai agent, atau pemerintah daerah sebagai principal dan satker sebagai agent (Kusuma \& Fuad, 2013). Di sektor publik, hubungan keagenan juga terlihat dalam penganggaran. Pemerintah daerah mempersiapkan anggaran, kemudian menyerahkan anggaran ke pusat untuk mendapat persetujuan, dan pemerintah daerah menjalankan kegiatan berdasarkan anggaran. Anggaran yang telah disetujui menjadi tanggungjawab pemerintah daerah (Zelmiyanti, 2016).

Anggaran adalah rencana formal dari suatu kegiatan, dinyatakan dalam nilai unit moneter. Menurut (Shah, 2007), pada sektor publik, penganggaran mencatat pendapatan dan belanja pemerintah selama periode tertentu, menyajikan kegiatan yang akan dilakukan pemerintah selama periode berjalan dan bagaimana pemerintah akan mendanai kegiatan tersebut. Lebih lanjut, (Shah, 2007) menjelaskan proses anggaran pemerintah yang meliputi empat tahap, yaitu keterlibatan instansi pelaksana pada tahap perencanaan, keterlibatan legislatif dalam tahap persetujuan, lembaga pelaksana yang melakukan tahap pelaksanaan, dan akhirnya lembaga audit yang terlibat dalam tahap pertanggungjawaban.

Pada setiap akhir tahun anggaran, penyerapan anggaran merupakan topik perbincangan yang hangat. Baik instansi pemerintah pusat maupun instansi pemerintah daerah berebut melaporkan penggunaan anggaran yang terbaik. Sebab, angka penyerapan anggaran masih dianggap sebagai indikator utama bentuk kinerja yang baik dan tingkat penyerapan anggaran yang rendah juga dapat berarti penganggaran yang tidak efisien. Hal ini sudah lazim, meski perlu dilakukan pengujian apakah angka penyerapan anggaran yang tinggi akan konsisten dengan kinerja pelayanan yang memuaskan, (Lestari et al., 2014). 
Peraturan Pemerintah Nomor 23 Tahun 2005 mengatur bahwa instansi pemerintah yang berbentuk BLU bertujuan untuk memberikan layanan prima berupa penyediaan serta penjualan barang dan jasa kepada masyarakat. Tujuan BLU tidak boleh semata-mata untuk memperoleh keuntungan (not-for-profit organization) dan mengembangkan produktivitas kegiatan berdasarkan prinsip efektifitas dan efisiensi. Instansi BLU ada yang dimiliki oleh pemerintah pusat, dan ada yang berupa BLU Daerah. Pola Pengelolaan Keuangan Badan Layanan Umum (PPK-BLU) merupakan model tata kelola keuangan yang menyuguhkan fleksibilitas dalam bentuk yang longgar untuk membentuk praktik bisnis yang sehat guna meningkatkan kualitas pelayanan. Peraturan Pemerintah ini mengatur lebih rinci dan memberikan tambahan khusus dari peraturan pengelolaan keuangan pemerintah lainnya yang bersifat umum.

Menurut Permendagri Nomor 13 Tahun 2006 yang mengatur mengenai tata kelola keuangan daerah, revisi atau perubahan APBD dilakukan karena capaian tidak memenuhi asumsi Kebijakan Umum APBD (KUA), dan dapat tidak memenuhi atau bahkan melebihi perkiraan pendapatan daerah, pengeluaran belanja daerah, dan sumber pendanaan murni yang telah diatur dalam dokumen KUA (Asmara, 2010). Menunjukkan bahwa revisi penganggaran merupakan kelanjutan dari proses penganggaran tahunan, dan sisa dana dalam anggaran tahunan dapat dialokasikan kembali ke tahun anggaran berjalan. Realisasi atau penyerapan anggaran yang tidak akurat dapat disesuaikan dengan perubahan anggaran. Purwanto (2016) mengemukakan bahwa perubahan anggaran merupakan kegiatan yang dilakukan oleh instansi pemerintah dalam mengubah rincian dan besaran anggaran pendapatan maupun belanja yang telah ditetapkan sesuai dengan APBN atau APBD dan disetujui dalam daftar pelaksanaan anggaran. Perubahan anggaran yang erat kaitannya dan tidak bisa dipisahkan dari proses penganggaran dan realisasi anggaran menjadi dasar pengajuan hipotesis pertama yaitu:

H1 = Perubahan anggaran memiliki pengaruh terhadap serapan anggaran

Negara dkk. (2018) menganalisis beberapa faktor yang dapat menjadi penyebab rendahnya tingkat penyerapan anggaran SKPD khususnya pada awal tahun, dan menunjukkan bahwa terdapat tiga faktor yang berpengaruh pada tingkat serapan anggaran. Faktor utama adalah kebijakan, administrasi dan sumber daya manusia. Ketiga faktor tersebut berdampak besar pada tingkat penyerapan anggaran, tingkat penyerapan anggaran seringkali rendah pada awal tahun sehingga terjadi penumpukan anggaran pada akhir tahun. Menurut (Rifai \& Inapty, 2016) meyakini bahwa satuan kerja yang memiliki sumber daya manusia yang baik dalam pelaksanaan rencana dan kegiatannya, maka penyerapan anggaran akan semakin baik karena mereka sudah memahami tanggung jawab dan fungsi utamanya (Tupoksi). Besarnya pengaruh SDM terhadap kinerja organisasi menjadi dasar hipotesis kedua yaitu:

$\mathrm{H} 2$ = Kualitas SDM memiliki pengaruh terhadap serapan anggaran 
Pengaruh dari luar individu disebut pengaruh atau tekanan eksternal. Jenis pengaruh ini tidak dapat diabaikan, individu harus mencoba menggunakan aspek positif dari pengaruh ini dan menggunakannya untuk memaksimalkan potensi diri. Tekanan eksternal dapat berupa peraturan perundang-undangan, budaya birokrasi, maupun tuntutan atau persyaratan atasan atau pemangku kepentingan. Regulasi adalah seperangkat peraturan yang disajikan sebagai pasal dan ayat yang mengatur suatu urusan. Salah satu kendala penyerapan anggaran selama ini adalah masalah regulasi. Semakin jelas peraturan dan semakin banyak diimplementasikan, semakin mudah bagi penerima amanah untuk melaksanakan rencana dan kegiatan pemberi amanah (Rifai \& Inapty, 2016). Tekanan eksternal di lingkungan SKPD akan mendorong penerapan transparansi pelaporan keuangan yang meningkat di pemerintah daerah (Pradita dkk, 2019). Tekanan eksternal yang erat dengan hubungan agen dan prinsipal ini dapat memotivasi setiap individu untuk mencapai tujuan bersama (Arifah, 2012). Dengan adanya tekanan eksternal yang dapat mendorong manajemen untuk bekerja lebih baik, maka diajukan hipotesis ketiga yaitu:

H3 = Tekanan eksternal memiliki pengaruh terhadap serapan anggaran

\section{Metode Penelitian}

Penelitian ini mengadopsi metode penelitian kuantitatif dengan melakukan pengujian hipotesis untuk memastikan adanya hubungan variabel dependen dengan variabel independen. Penelitian ini menggunakan jenis penelitian korelasional twotailed yang mengilustrasikan hubungan antar variabel dependen dan variabel independen berdasarkan hipotesis penelitian yang tidak ditentukan arahnya.

Sumber data analisis yang dipakai dalam penelitian ini adalah perorangan yaitu pegawai yang menduduki jabatan di bidang pengelolaan anggaran seperti Pejabat Pembuat Komitmen (PPK), Bendaharawan, Bagian Perencanaan, Bagian Akuntansi, Unit Layanan Pengadaan (ULP), panitia pengadaan barang dan jasa, dan yang sejenisnya yang bekerja pada BLU dan BLUD. Kuisioner didistribusikan kepada para pegawai di beberapa instansi berbentuk BLU dan BLUD yang berada di daerah Kabupaten Banyumas, Kabupaten Cilacap, dan Kabupaten Brebes yaitu Universitas Jenderal Soedirman Purwokerto, RSUD Cilacap, RSUD Bumiayu dan RSUD Majenang.

Jenis data sekunder yang digunakan adalah data laporan realisasi anggaran dan laporan yang terkait dengan pelaksanaan anggaran belanja. Data primer diperoleh dari responden secara langsung dengan memanfaatkan aplikasi Google Form untuk pengisian kuesioner yang dibagikan kepada para responden. Jumlah responden yang berpartisipasi dalam pengisian kuisioner tidak dibatasi.

Berdasarkan variabel yang digunakan, kuesioner mencakup 4 bagian pertanyaan. Kuisioner berupa susunan pertanyaan berjumlah 31 poin yang diajukan kepada para responden dan diisi berdasarkan persepsi masing-masing individu, lalu hasilnya dinilai dengan menggunakan skala likert. Penelitian ini menggunakan lima pilihan jawaban meliputi: sangat setuju (SS), setuju (S), kurang setuju (KS), tidak setuju (TS), dan 
sangat tidak setuju (STS). Skor yang didapatkan untuk pilihan sangat setuju (SS) bernilai 5, setuju (S) bernilai 4, kurang setuju (KS) bernilai 3, tidak setuju (TS) bernilai 2, dan jawaban sangat tidak setuju (STS) bernilai 1.

Setelah tahap pengumpulan hasil kuisioner, proses selanjutnya adalah analisis dan olah data, lalu proses pengujian data. Pertama yang dilakukan adalah uji validitas dan reliabilitas untuk menguji apakah poin-poin dalam kuisioner valid dan reliabel. Dengan menggunakan pilot test telah diketahui bahwa susunan pertanyaan adalah valid dan reliabel. Kemudian dilakukan uji normalitas, uji multikolinieritas, dan uji heteroskedastisitas. Analisis data dalam penelitian ini dilakukan dengan menggunakan analisis regresi linier berganda dengan bantuan program SPSS.

\section{Hasil dan Pembahasan}

\section{Uji Normalitas}

Menurut (Ghozali, 2018) menyampaikan bahwa model regresi yang hasilnya memunculkan data sesungguhnya mengikuti garis miring atau diagonal maka dapat dikatakan berdistribusi normal.

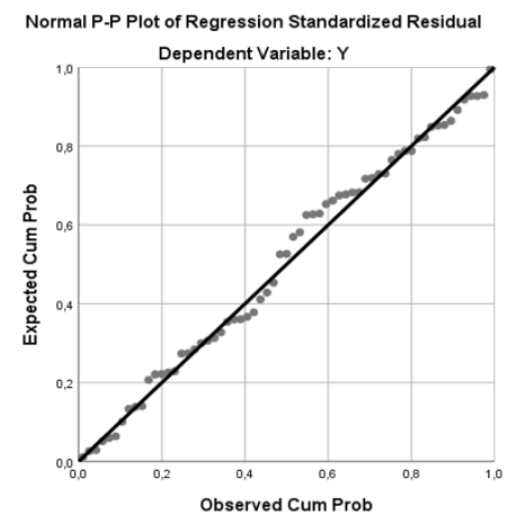

Gambar 1. Hasil SPSS Uji Normalitas

Dapat dijelaskan dari gambar 1 bahwa titik-titik data seirama dengan garis diagonal, sehingga berarti data sudah berdistribusi normal atau didapat dari populasi yang normal.

\section{Uji Multikolinieritas Tolerance \& VIF}

Menurut (Ghozali, 2018) menyatakan gejala multikolinieritas tidak terjadi jika angka tolerance bernilai diatas 0,100 dan angka VIF berada dibawah 10,00. Uji multikolinieritas berfungsi untuk menguji apakah ketiga variabel independen yang digunakan memiliki keterkaitan yang erat satu sama lain. Jika terdapat keterkaitan, maka variabel tidak sah digunakan dalam penelitian. 


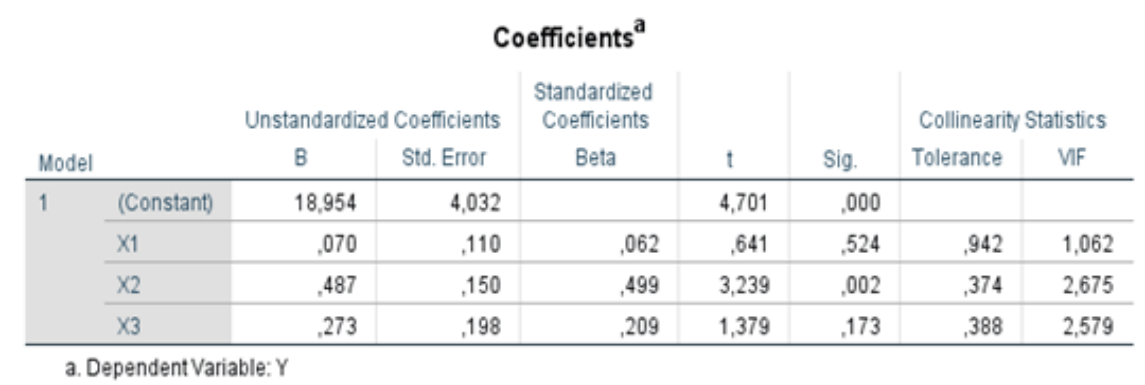

Gambar 2. Hasil SPSS Uji Multikolinieritas

Gambar 2 menunjukkan seluruh nilai tolerance dari ketiga variable independen berada diatas 0,100 dan seluruh nilai VIF berada dibawah 10,00. Artinya tidak terjadi gejala multikolinieritas pada model penelitian.

\section{Uji Heteroskedastisitas Scatterplots}

Heteroskedastisitas tidak terjadi jika pola hasil uji tidak ada yang jelas atau tidak membentuk pola (membentuk garis, bergelombang, menyempit, atau melebar) pada gambar scatterplots. Pola titik-titik tersebut didistribusikan di atas dan di bawah 0 pada sumbu Y (Ghozali, 2018). Heteroskedastisitas adalah alat uji yang mengevaluasi apakah terdapat ketidaksamaan varian residual untuk semua pengamatan penelitian dalam model regresi linier.

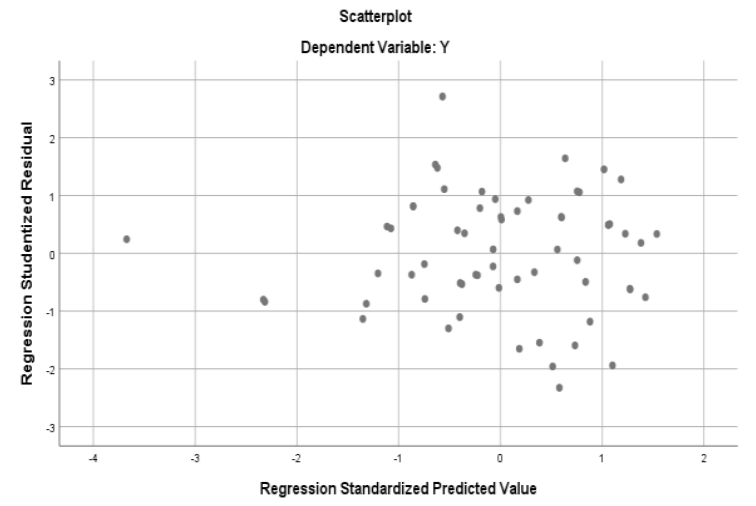

Gambar 3. Hasil SPSS Uji Heteroskedastisitas

Gambar 3 menunjukkan bahwa pola menyebar secara acak tidak beraturan. Hal ini berarti tidak terjadi heteroskedastisitas.

\section{Uji Autokorelasi Durbin Watson}

Autokorelasi tidak terjadi jika hasil uji autokorelasi berupa nilai Durbin Watson terletak antara du sampai dengan 4-du (Ghozali, 2018). Nilai du didapatkan dari tabel hitung Durbin Watson. Nilai du dengan responden berjumlah 63 adalah 1,6932 dan 41,6932 adalah 2,3068. Sehingga nilai Durbin Watson harus berada diantara $1,6932<\mathrm{DW}<2,3068$. Didapatkan hasil 2,074 dari gambar 4 yang berarti model penelitian ini tidak terjadi autokorelasi. 


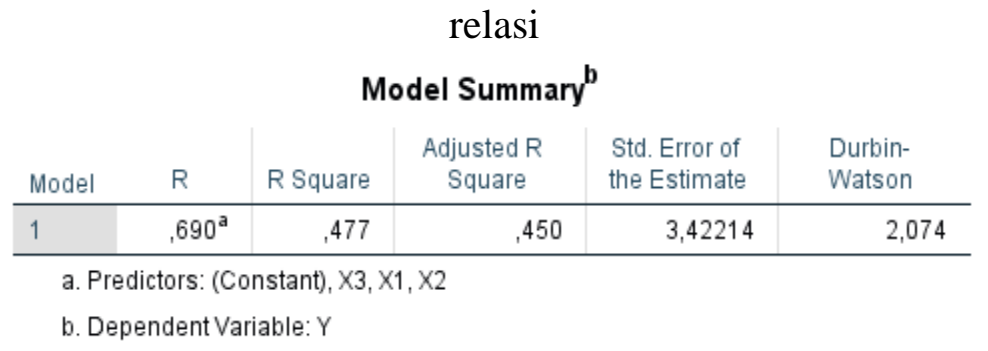

Gambar 4. Hasil SPSS Uji Autoko

\section{Uji Signifikansi Individual (Uji t Parsial)}

Mengacu pada (Ghozali, 2018), apabila hasil signifikansi kurang dari 0,05 maka artinya variabel independen $(\mathrm{X})$ berpengaruh secara parsial terhadap variabel dependen (Y).

\begin{tabular}{|c|c|c|c|c|c|c|c|c|}
\hline \multicolumn{9}{|c|}{ Coefficients $^{\mathrm{a}}$} \\
\hline \multirow[b]{2}{*}{ Model } & & \multicolumn{2}{|c|}{ Unstandardized Coefficients } & \multirow{2}{*}{$\begin{array}{c}\text { Standardized } \\
\text { Coefficients } \\
\text { Beta }\end{array}$} & \multirow[b]{2}{*}{$t$} & \multirow[b]{2}{*}{ Sig. } & \multicolumn{2}{|c|}{ Collinearity Statistics } \\
\hline & & B & Std. Error & & & & Tolerance & VF \\
\hline \multirow[t]{4}{*}{1} & (Constant) & 18,954 & 4,032 & & 4,701 &, 000 & & \\
\hline & $\mathrm{X}_{1}$ &, 070 &, 110 & .062 & 641 & .524 & .942 & 1,062 \\
\hline & $x_{2}$ & .487 &, 150 & .499 & 3,239 & .002 & .374 & 2,675 \\
\hline & $x_{3}$ &, 273 &, 198 & 209 & 1,379 &, 173 &, 388 & 2,579 \\
\hline
\end{tabular}

Gambar 5. Hasil SPSS Uji t Parsial

Perubahan anggaran (X1) mendapatkan signifikansi 0,524, kualitas SDM mendapatkan 0,002, dan tekanan eksternal (X3) mendapatkan 0,173. Variabel X1 dan X3 lebih dari 0,05, artinya $\mathrm{H} 1$ dan $\mathrm{H} 3$ ditolak karena variabel perubahan anggaran dan tekanan eksternal tidak berpengaruh signifikan terhadap serapan anggaran. Sedangkan kualitas SDM (X2) mendapatkan 0,002 kurang dari 0,5 berarti kualitas SDM berpengaruh signifikan terhadap serapan anggaran dan hipotesis $\mathrm{H} 2$ diterima.

Hasil ini sesuai dengan penelitian (Santoso, 2017). Yang menyebutkan bahwa di dalam organisasi, keberadaan manusia memiliki posisi yang sangat vital. Berhasil tidaknya organisasi sangat bergantung pada kualitas pegawainya. Sejalan dengan penelitian (Rifai \& Inapty, 2016) mengenai perencanaan dan regulasi terhadap serapan anggaran, variabel tekanan eksternal yang didalamnya terdapat indikator kepatuhan terhadap peraturan dan prosedur tidak berpengaruh signifikan terhadap serapan anggaran. Variabel perubahan anggaran tidak berpengaruh terhadap serapan anggaran, hal ini berbeda hasilnya dengan penelitian (Lestari et al., 2014) yang masing-masing menyebutkan bahwa perubahan anggaran berpengaruh positif dan negatif terhadap serapan anggaran.

\section{Uji model / anova (Uji F simultan)}


Menurut (Ghozali, 2018) menyebutkan apabila nilai signifikansi dibawah 0,05, hal ini berarti variabel independen (X) secara simultan / bersama-sama berpengaruh terhadap variabel dependen $(\mathrm{Y})$.

Gambar 6. Hasil SPSS Uji F simultan

\begin{tabular}{|c|c|c|c|c|c|c|}
\hline \multicolumn{7}{|c|}{ ANOVA $^{\mathrm{a}}$} \\
\hline Model & & $\begin{array}{l}\text { Sum of } \\
\text { Squares }\end{array}$ & $d f$ & Mean Square & $\mathrm{F}$ & Sig. \\
\hline \multirow[t]{3}{*}{1} & Regression & 629,050 & 3 & 209,683 & 17,905 &, $000^{\mathrm{b}}$ \\
\hline & Residual & 690,950 & 59 & 11,711 & & \\
\hline & Total & 1320,000 & 62 & & & \\
\hline
\end{tabular}

Kesimpulan dari hasil uji $\mathrm{F}$ pada gambar 6, perubahan anggaran (X1), kualitas SDM (X2), dan tekanan eksternal (X3) bersama-sama berpengaruh signifikan terhadap serapan anggaran (Y). Artinya ketiga variabel independen dapat digunakan bersama sebagai model indikator variabel dependen berupa serapan anggaran.

\section{Kesimpulan}

Kesimpulan yang dapat diambil dari penelitian ini yang pertama yaitu, tujuan penelitian adalah untuk menguji pengaruh perubahan angaran, kualitas SDM, dan tekanan eksternal terhadap serapan anggaran. Kedua, penelitian dilakukan menggunakan kuisioner pada beberapa instansi pemerintah berbentuk badan layanan umum dengan responden yang didapatkan sejumlah 63 orang dari empat instansi BLU. Ketiga, berdasarkan hasil uji statistik, hanya kualitas SDM yang seraca parsial berpengaruh signifikan terhadap serapan anggaran, dan secara simultan ketiganya bersama-sama berpengaruh terhadap serapan anggaran. Kesimpulan akhir, bahwa SDM merupakan aset berharga dari organisasi yang dapat menjadi penentu baik buruknya kinerja dari sebuah organisasi. Bisa dikatakan hampir semua permasalahan yang dihadapi oleh sebuah organisasi selalu terkait dengan SDM yang ada di dalamnya. Dengan adanya sumber daya manusia yang berkualitas baik, tujuan organisasi akan mudah tercapai dan hubungan antara prinsipal dan agen terjalin dengan baik.

Keterbatasan penelitian ini adalah akses yang relatif sulit ke instansi responden yang sebagian besar membutuhkan perijinan yang lama, sehingga peneliti hanya mendapatkan 63 responden dari empat instansi BLU dan BLUD. Penelitian selanjutnya diharapkan dapat memperluas cakupan wilayah penelitian dan menggunakan variabel lainnya. 


\section{Bibliography}

Andriati, R. (2019). Factors Affect Budget Absorption in Government Institutions of Indonesia, 2017. Journal of Governance and Public Policy, 6(2), 101-109.

Arifah, D. A. (2012). Praktek Teori Agensi pada Entitas Publik dan Non Publik. PRESTASI, 9(01).

Asmara, J. A. (2010). Analisis perubahan alokasi belanja dalam anggaran pendapatan dan belanja daerah (APBA) Provinsi Naggroe Aceh Darussalam. Jurnal Telaah Dan Riset Akuntansi, 3(2), 155-172.

Dewi, I. M., \& Purbawangsa, I. B. A. (2018). Pengaruh Literasi Keuangan, Pendapatan Serta Masa Bekerja Terhadap Perilaku Keputusan Investasi. E-Jurnal Ekonomi Dan Bisnis Universitas Udayana, 7(7), 1867.

Ghozali, I. (2018). Aplikasi analisis multivariete dengan program IBM SPSS 23.

Halim, A., \& Kusufi, M. S. (2007). Akuntansi sektor publik: Akuntansi keuangan daerah. Jakarta: Salemba Empat.

Kusuma, M. I. Y., \& Fuad, F. (2013). Analisis faktor-faktor yang mempengaruhi tingkat penerapan akuntansi akrual pada pemerintah. Fakultas Ekonomika dan Bisnis.

Lestari, S., Abdullah, S., \& Basri, H. (2014). Pengaruh Alokasi Belanja Murni Dan Alokasi Belanja Perubahan Terhadap Serapan Anggaran Kabupaten/Kota Di Aceh. Jurnal Administrasi Akuntansi: Program Pascasarjana Unsyiah, 3(3).

Mardiasmo, D., \& MBA, A. (2009). Akuntansi Sektor Publik. Yogyakarta: Andi.

Putri, N. W. (2015). Studi Eksploratif Tentang Faktor-faktor Yang Mempengaruhi Perubahan Anggaran Keuangan (PAK) Pada Dinas Pengelolaan Bangunan Dan Tanah Kota Surabaya. UNIVERSITAS AIRLANGGA.

Rifai, A., \& Inapty, B. A. (2016). Analisis Faktor-Faktor yang Memengaruhi Keterlambatan Daya Serap Anggaran (Studi Empiris Pada SKPD Pemprov NTB). Jurnal Ilmiah Akuntansi Dan Bisnis, 11(1).

Santoso, T. (2017). Pengaturan tindak pidana pemilu di empat negara asia tenggara. Jurnal Hukum \& Pembangunan, 34(2), 129-142.

Shah, A. (2007). Budgeting and budgetary institutions. World Bank Publications.

Yulianti, N. W. (2019). Serapan Anggaran UIN Syarif Hidayatullah Jakarta: Sebelum dan Sesudah Revisi Anggaran. Akuntabilitas, 12(1), 37-52.

Zelmiyanti, R. (2016). Pendekatan teori keagenan pada kinerja keuangan daerah dan 
Analisis Serapan Anggaran pada Instansi Badan Layanan Umum

belanja modal (Studi pada Provinsi di Indonesia). JRAK: Jurnal Riset Akuntansi Dan Komputerisasi Akuntansi, 7(1), 11-21. 